ENGLISH COMEDY 
By the same Author

THE COMMON MUSE

(Foint Editor with V. de S. Pinto)

THE ROMANTIC CONFLICT

THE TRUTHS OF FICTION 


\title{
English Comedy
}

ITS ROLE AND NATURE FROM

CHAUCER TO THE PRESENT DAY

\author{
by \\ ALLAN RODWAY \\ Reader in English \\ in the University of Nottingham
}

UNIVERSITY OF CALIFORNIA PRESS

Berkeley and Los Angeles 1975 
UNIVERSITY OF CALIFORNIA PRESS

Berkeley and Los Angeles, California

Library of Congress Catalog Card Number: 74-25377

All rights reserved. No part of this publication may be reproduced, stored in a retrieval system, or transmitted in any form, or by any means, electronic, mechanical, photocopying, recording or otherwise without the prior permission of the publisher.

ISBN: 0-520-02935-6

(C) Allan Rodway 1975

Printed in Great Britain 


\section{TO \\ MY WIFE}


